\title{
圈 \\ Financial Stress, Financial Literacy, Counselling and the Risk of Homelessness
}

Adam Steen ${ }^{1}$ and David MacKenzie, The Swinburne Institute, Swinburne University

\begin{abstract}
Poor financial literacy may lead to poor life choices. These life choices can create or contribute to financial stress with adverse consequences - not the least of which may be homelessness. These issues are relatively well understood, but there is limited research on the link between financial stress, financial literacy and counselling, and homelessness. Specifically, there has been little research on how improved financial literacy and appropriate financial counselling might help to prevent homelessness. This paper synthesises existing literature on this topic and considers these issues using the ABCX family stress model of Hill (1958) using data from an Australian program aimed at alleviating family homelessness, the Home Advice Program. We provide evidence that suggests that case management and support which incorporates financial counselling and financial literacy can assist in moderating the impact of financial stress and help those at risk of homelessness. The findings have implications for public policy in the areas of financial education, consumer finance, and social services provision.
\end{abstract}

Keywords: Financial stress; Financial literacy; Homelessness.

JEL Classification: I39; D14

\footnotetext{
${ }^{1}$ asteen@swin.edu.au
} 


\section{Introduction}

Financial stress has been defined as a situation of having insufficient financial resources to meet basic requirements to maintain a reasonable standard of living (Yates, 2007). Financial stress incorporates many aspects of financial circumstances including income, debts, assets and money management. It focuses on the effect that financial circumstances have on a person's standard of living by considering deprivation specific to the community in which they live. The proportion of individuals and families experiencing financial stress varies from country to country. In Australia, for example, an estimated 18-44 per cent of households experience some degree of financial stress (Bray, 2001; Marks, 2007). Hence, it is a significant issue in Australia, as it is elsewhere (Worthington, 2006b), because the degree of financial stress experienced by individuals and families has implications for physical and mental health as well as participation in society. While financial stress is more common in low-income households, it is also experienced by those with higher incomes and affects people in different ways (Bray, 2001).

Several interacting factors have been identified as contributing to financial stress, highlighting the complexity of pathways into and out of this state. These factors can be summarised as: 'unhealthy financial ways of thinking', 'circumstances outside the individual's control', and 'lack of skills and knowledge' (Australia and New Zealand Banking Group Limited (ANZ), 2005; Marston \& Shevellar, 2010). Unhealthy financial ways of thinking include a lack of care in managing finances or wanting to live above one's means. Circumstances largely outside the individual's control include divorce, job loss, health issues, relationship issues, death of income earner, both expected and unexpected pregnancy, child rearing costs, and involvement in a struggling small business. The last factor recognises that some people lack skills and knowledge about how to effectively manage their finances.

The ability to make informed financial judgements and effectively manage one's own money is known as 'financial literacy'. Certain subgroups of Australian society have been identified as having a high proportion of people with low levels of financial literacy, including the young, welfare recipients, and low income earners (ANZ, 2008). A low level of financial literacy, in particular the inability to effectively manage money when accompanied by unhealthy financial ways of thinking, are factors contributing to financial difficulty (ANZ, 2008). The ANZ bank (2005) has suggested that increasing financial literacy, as well as increasing use of community-based financial counsellors, could play an important role in overcoming financial stress.

Financial stress can have severe short as well as long-term consequences for individuals, families and the community. The common experience of those undergoing financial stress is isolation, despair, and depression which may also be accompanied by relationship breakdown (Relationships Australia, 2008), substance abuse, increased or frequent gambling, and domestic violence (Wesley Mission, 2006). Financial stress can adversely affect an individual's physical and mental health (Saunders, 1998) and has been identified as a cause of homelessness (MacKenzie et al., 2007). Financial stress has been noted as a pre-cursor to financial exclusion; the inability to access mainstream financial institutions, forcing individuals to use fringe lenders with high interest rates (Connolly et al., 2011). This often leads to increasing debt to unmanageable levels (ANZ, 2005; Chant Link \& Associates, 2004; Marston \& Shevellar, 2010). Financial exclusion in turn reinforces social exclusion (Chant Link \& Associates, 2004).

Financial stress is a significant issue affecting individuals, families and communities, and is perpetuated by a complex array of factors. Governments and welfare agencies in Australia as elsewhere have attempted proactive strategies to mitigate financial stress through financial literacy programs and financial counselling. This paper investigates the relationship between financial stress, financial literacy, financial counselling and homelessness. In so 
doing it is the first paper to explicitly bring together all of these issues. We employ a case study approach using evaluation data from a pilot early intervention program aimed at preventing family homelessness, the Household Organizational Management Expense (HOME) Advice Program. After an examination of the relevant literature we draw on the well-known theoretical model of family stress developed by Hill (1949). Using the results of the program we illustrate how improving financial literacy and providing appropriate financial counselling could positively contribute to strategies aimed at moderating the impact of family financial stress and the risk of homelessness.

The remainder of this paper is organised as follows. In Section 1 we review studies which have dealt with financial stress and homelessness and those that have dealt with financial literacy and financial stress. We also look at Australian studies which have considered homelessness and financial literacy. In Section 2 we introduce the ABCX model of family stress as a basis for analysing the results of the HOME Advice Program. Section 2 also provides background to the program. Section 3 provides analysis of results of the intervention trial as they relate to the issues of financial stress, literacy and counselling. Section 4 provides concluding comments, policy implications and recommendations for future research.

\section{Literature Review}

\section{Financial Stress and Homelessness}

Bray (2001) classifies the varying degrees of financial stress in rank order from least to most severe as 'missing out', 'cash flow problems', and 'hardship'. 'Missing out' is the inability to afford participation in activities that are recognised by society as important for a reasonable standard of living such as going on an annual holiday. 'Cash flow problems' include having insufficient money to pay for daily expenses or regular household bills. 'Hardship' refers to the situation of having to go without basic needs such as food and electricity and having to seek emergency financial relief.

While financial stress does present some individuals and families with serious problems, the experience of financial stress for many could also be viewed as part of normal household budgeting and prioritising (Bray, 2001). Many households are able to survive an episode of financial stress provided they are sufficiently financially literate and have the structures to enable them to navigate their way through difficulties. However, severe financial stress, as indicated by multiple cash flow problems, is estimated to have affected ten per cent of Australian families in 2007 (Marks, 2007). The ten per cent identified represents a significant number of Australians and includes a high number of children less than 15 years of age (Bray, 2001).

While certain groups within society may be disproportionately affected by financial stress than other groups, it is experienced across income levels, age ranges, and household types. Increased incidence of financial stress is positively associated with low income, unemployment, receipt of welfare, and living in rental housing (Bray, 2001). Single-parents are estimated to be two to three times more likely to experience financial stress than coupleheaded families (Bray, 2001; Breunig \& Cobb-Clark, 2004; Marks, 2007). Other groups known to be at increased risk of financial stress include young people (Marks, 2007), indigenous Australians (Marks, 2007), and those with a disability (Bray, 2001).

Children in low income families have been found to be particularly adversely impacted by financial stress. In a study of single parents on income support in the Australian Capital Territory, Winkworth et al. (2009) reported financial stress inhibited service usage and significantly reduced social supports. Moore et al. (2009) also found that young carers in 
families affected by alcohol and other drugs reported financial hardship such as lack of food, unstable housing, and missing out on social activities.

Several precipitating events and causes have been linked to homelessness including financial stress, poor health, psychological issues, substance abuse, and family breakdown (Commonwealth of Australia, 2008). Many, if not most homeless people have multiple needs including housing, financial assistance, healthcare and social support (Darbyshire et al., 2006; O’Neill et al., 1995).

Some recent studies have considered the impact of financial stress and homelessness on various types of families. Burgess and Roberts (2003) and Roberts and Burgess (2004) have found that financial stress is a major contributing factor towards homelessness among indigenous families in Australia. In the United States, Gutman et al. (2005) found financial stress was a contributor to psychological stress and homelessness amongst urban African American families, while Wehler et al. (2004) note that homelessness may result from diminished personal, financial, and social resources in female-headed families.

Using 1991 to 1997 data from the British Household Panel Survey, Boheim and Taylor (2000) investigated the incidence of housing finance problems, evictions, and repossessions. Their results show that whilst controlling for other changes such as divorce or loss of employment, previous experience of financial problems had a significant and positive association with individuals' current financial situation, and that negative financial surprises are the main route into financial difficulties. They confirm the importance of structural, financial, and personal factors in determining housing payment problems. Families with higher income, where at least one parent is working, and those with greater assets have a lower risk of experiencing problems meeting their housing costs.

Anderson et al. (1993) and Kemp et al. (2004) find bereaved people are particularly at risk of problem debt and poverty. Corden and Hirst (2007) identified that the death of a life partner and the financial stress that it causes can be contributing factors for depression and homelessness.

Crane and Warnes (2001) studied homeless older individuals. Some had become homeless for the first time in old age, having been married and working for many years. Others had spent most of their adult lives in hostels or on the streets. Numerous events and states triggered and contributed to their homelessness. Although homelessness was generally associated with shortages of low-cost rented housing, unemployment and poverty, personal and psychosocial factors also had a dominant role. They note that some men in their study reported that they became lonely and bored when they retired. For some, this had led to heavy drinking, which in turn contributed to rent defaulting and homelessness. Compounding all of these issues for some were financial problems experienced due to inability or unwillingness to claim welfare benefits or state pensions. Crane et al. (2005) note that low income, lack of financial reserves and social support, and poor money management skills often lead older adults into financial difficulties, sometimes resulting in homelessness.

It has also been found that financial stress is not confined to those on welfare. Berger and Tremblay (1999) note that for renters or homeowners who live from pay cheque-to-pay cheque, any financial crisis can lead to eviction and ultimately, homelessness.

Financial stress combined with homelessness, can, as Vissing (2007) notes, impact on a child's sense of self and well-being, and this could have long-term consequences for children growing up in families which experience homelessness.

\section{Financial Literacy and Financial Stress}

Norman (2010) found that most financial stress is largely caused by poor spending decisions precipitated by a lack of adequate financial literacy. However, basic literacy is a precondition 
to financial literacy. As Betal (2004, p.23) states; "literacy and numeracy skills are a prerequisite in developing financial literacy". What is evident from the literature is the lack of coherent definition of financial literacy and agreed measurement techniques. Recently, Huston (2010) surveyed studies concerning financial literacy and financial knowledge. Of the seventy-one individual studies published between 1996 and 2008, 72 per cent did not include a definition of financial literacy, while 88 per cent did not include a guide for measurement interpretation. After reviewing the literature, Huston (2010) proposed that:

"financial literacy is a component of human capital that can be used in financial activities to increase expected lifetime utility from consumption (i.e. behaviors that enhance financial well-being). Other influences (such as behavioral/cognitive biases, self-control problems, family, peer, economic, community and institutional) can affect financial behaviors and financial well-being” (Huston, 2010, p.307-8).

According to Huston, financial literacy consists of knowledge and application of human capital specific to personal finance. The level of endowed and attained human capital influences a person's financial literacy.

Worthington (2006a) categorises the literature on financial literacy into two groups: firstly, those papers that attempt to explain the differing patterns of financial literacy in the population (Schagen \& Lines, 1996; Mandell, 1998; Jumpstart Coalition for Personal Financial Literacy, 2005) and secondly, those that attempt to evaluate the efficacy of individual financial literacy programs (Huddleston \& Danes, 1999; Garman et al., 1999; Chatzky, 2002).

Worthington (2006a) found financial literacy in Australia to be highest amongst people aged between 50 and 60, professionals, business and farm owners, and university and college graduates. Financial literacy was lowest for unemployed, females, and those from non-English speaking backgrounds with a low level of education. Such findings are consistent with those of de Clercq and Venter (2009) who found financial literacy dependent on gender, age, and language. Other research in Australia has indicated that young people are particularly lacking in basic financial knowledge (Australian Law Reform Commission, 1997; Roy Morgan Research, 2003a, 2003b, 2003c).

Worthington's 2006(a) study used data from Roy Morgan Research's (2003b) survey of 3,548 respondents which formed the basis of the ANZ Survey of Adult Financial Literacy in Australia. As data originated from a telephone survey, it is doubtful whether many homeless persons were included. The survey was designed to measure financial literacy by collecting and analysing respondents:

- Mathematical and standard literacy with questions designed to test mathematical, reading and comprehension skills;

- Financial understanding with questions to evaluate understanding of what money is, how it is exchanged, and where it comes from and goes;

- Questions on financial competence which aimed to check understanding of basic financial services, financial records, awareness of risk and return, and attitudes toward spending and saving; and,

- Questions on financial responsibility used to confirm knowledge of life choices, rights and responsibilities, and confidence when resolving problems. 
In the UK, Wallace and Quilgars (2005) noted the problem of poor financial literacy is particularly acute amongst young homeless people. The young adults they studied were not in employment, education or training and were particularly lacking in financial capabilities, lacked knowledge of how to open a bank account, were unclear about interest rates, did not know how to compare different credit options and lacked experience in paying household bills. These results are consistent with the findings of other UK-based studies such as Centrepoint (2005) which noted that young homeless people lacked literacy, numeracy, and financial literacy skills and regretted taking credit commitments earlier in life. The Centrepoint (2005) study found 20 per cent of those studied had received the marketing of lending institutions material while living in hostels.

\section{Homelessness and Financial Literacy in Australia}

Chamberlain and MacKenzie (2001) estimate that there are around 100,000 homeless men, women and children in Australia at any one time. Some may be homeless for an extended period, while others may be homeless for only days or weeks. It is common for homeless people to move in and out of stable accommodation, causing fluctuations in the homeless population over the course of a year. Although the number of homeless families cannot be easily calculated, there is some reliable national level information on which to base an estimate.

Few families, couples or single parents with children, spend time sleeping rough. In rural areas, families in a primary homelessness situation are more likely to be residing in an improvised dwelling and this may be their permanent or semi-permanent way of life $^{2}$. Likewise, it is difficult to establish the proportion of families in boarding houses. Hence the number of homeless families is an estimate because complete household data is not available for all sectors of the homeless population.

The average time families spend homeless has been estimated to be 6-7 months (Chamberlain \& MacKenzie, 2001). Following the method set out in the HOME Advice Program Evaluation Report (MacKenzie et al., 2007), the number of families at risk of homelessness can be estimated using the Homeless Indicator (HIND) which derives a number of homeless families by state and territory from Australian Bureau of Statistics (ABS) census data and the Rental Indicator (RIND) estimate using ABS data of families in private rental accommodations at risk of homelessness ${ }^{3}$. Using the two different methods provides estimates of a point-in-time population of between 7,800 (using the HIND estimate) and 15,800 (using the RIND estimate) families at risk of becoming homelessness in Australia (MacKenzie et al., 2007).

The turnover of clients, including families passing through the Australian Government's Supported Accommodation Assistance Program (SAAP), suggests point-intime figure and annual figures are not equal. The 'at-risk' population over a year could be twice the point-in-time estimate (between 15,800 and 31,600), but there is no simple way of estimating this multiplier. The estimated number of homeless families in Australia illustrates

\footnotetext{
2 Chamberlain and MacKenzie (1992) note that primary homelessness (also referred to as absolute homelessness) is characterised by living on the streets in deserted buildings or improvised dwellings. Primary homelessness can be contrasted with secondary or tertiary homelessness (often referred to as relative homelessness) which includes situations such as living in boarding houses, using SAAP or other emergency accommodation without security of tenure or staying with family and friends.

${ }^{3}$ A detailed description of the HIND and RIND indicators can be found at http://www.fahcsia.gov.au/sa/housing/pubs/housing/documents/home_report_html/appen1.htm
} 
the seriousness of the problem and highlights the need to address the causes of homelessness by implementing effective prevention and alleviation strategies.

It has been acknowledged that the inability to manage finances is a contributing factor to homelessness (see for example De Panfilis 1999). As a response, homelessness programs have adopted addressing financial issues and improving financial literacy amongst client case goals. Gowdy et al. (1993), for example, classify client outcomes of programs addressing homelessness as including:

- Changes in client knowledge, e.g., increased knowledge of appropriate disciplinary responses in stages of child development, an understanding of the cycle of domestic violence;

- Changes in client behaviour, e.g., demonstrating budgeting or cooking skills, reduction in substance abuse; and,

- Changes in client status, e.g., change from unemployed to employed.

Counselling programs that attempt to improve financial literacy aim to change client's knowledge while those that provide financial counselling may aim to change client's circumstances e.g. resolve an immediate financial crisis. For example, the Western Australian Independent Living Program (ILP) provides housing support to enable homeless people with severe and persistent mental illness to live independently in the community. The services provided through the ILP include disability support in the areas of personal care, budgeting and other daily living skills, and clinical support, provided through public mental health services.

In addition to the ILP, another Western Australian program, the Supported Housing Accommodation Program (SHAP), assists families at risk of becoming homeless. A report on the program found that financial difficulties leading to relationship breakdown, together with poor management skills, as well as mental health and addiction problems are frequently reported as factors contributing to homelessness. The program offers various services including assistance with improving housekeeping skills and budgeting; dealing with domestic violence, child abuse, drug and alcohol problems; and mental illness (Flatau et al., 2006).

\section{Theoretical Background and Method}

In his well-known ABCX model, Hill (1949 and 1958) theorised that major stressful events disrupt family equilibrium. Like other organisms, the family seeks to re-establish equilibrium by using coping mechanism to handle the stress. Hill identified financial stress as one of the stressful events that families frequently face. Other stressful events cited by Hill and others include divorce, physical abuse of children or spouses, illness, substance abuse and relapse, accidents and any other sudden onset events.

Hill proposed two protective factors at work within the family that help buffer it against the negative consequences of sudden stress. The first protective factor includes internal and external family resources and social support through church, community or other resources. Families with strong social ties prove better able to cope with sudden onset stress than families with poor social ties.

The second protective factor refers to shared family beliefs and perceptions of the stressor e.g., the extent to which the family perceived the changes as a disaster versus an opportunity. Hill suggested that if families perceived stressful events positively or constructively, they were better able to cope with the event. Those families that perceived and dwelled on the negative impact of the stressful event had a more difficult time coping with it. 
These two protective factors moderate the impact of the stressful event. If the family does not adapt to the stressful event and cope with it, they may end up in crisis.

Other theorists such as McCubbin and Patterson (1982, 1983(a) and 1983(b)) have added onto Hill's original model, but Hill's model remains the basis for family stress theory. Numerous papers have been written on the area of family stress since Hill with many dealing with questions relating to how much and what kinds of stressors lead to crisis as well as the methods, resources and coping responses which shape the course of family adjustment.

The existing literature indicates linkages between financial stress and homelessness (Burgess \& Roberts 2003; Roberts \& Burgess 2004) while various research studies have found links between financial literacy and financial stress (DePanfilis 1999). What has not been considered is the moderating impact of the provision of financial literacy and financial counselling support on families experiencing financial stress. Accordingly, our proposition is that for families experiencing financial stress, interventions involving the provision of financial literacy and financial counselling support can reduce financial stress and in turn reduce the risk of homelessness.

Given the relationships between financial stress, financial literacy, financial counselling support and homelessness are relatively unexplored it was felt that a case study research approach to further investigate these links was appropriate. Following the recommendations of Yin (1994) and Eisenhardt (1989) we employed an explanatory case study methodology. Saunders et al. (2007) note that an exploratory study is an appropriate method of determining what's happening, to seek new insights, ask questions, and assess phenomena in a new light. The advantage of this approach is its flexibility and adaptability. The flexibility inherent in exploratory research means that our focus could become increasingly narrower as the study progressed arriving at specific conclusions based on generalisations.

We explore the link between financial stress, financial counselling and financial literacy and homelessness using the case of the HOME Advice Program. This was a national early intervention pilot program subject to an evaluation in 2005-2006 (MacKenzie et al. 2007). The authors were given permission to use the data from the evaluation in the preparation of this paper. The data from the program evaluation provides a unique opportunity to provide additional insights into the topic.

While the SHAP program was confined to the state of Western Australia, the Australian Government trialled a national early intervention program aimed at assisting families at risk of becoming homeless starting in 2006. The HOME Advice Program was developed as a response to family crises involving many issues, but in all cases these were accompanied by a financial crisis leading to the family being identified as 'at risk' of becoming homeless. The policy thinking underpinning the HOME Advice Program was that prevention of homelessness was possible and that for many families it was a housing/financial crisis that was the main source of their slide towards homelessness. Also, the new program represented a shift in policy thinking towards 'early intervention' and prevention in addition to the established provision of services for homeless families and children. In 2005-2006, \$A323.9 million was spent on homelessness services through the Supported Accommodation Assistance Program (SAAP), the Australian Government's homeless assistance program. Some 30 per cent of SAAP clients are families with approximately 54,700 accompanying children. The philosophy behind HOME Advice was that without early intervention and prevention many 'at risk' families will become homeless families; with appropriate support the slide into homelessness may be avoided for many.

The HOME Advice Program began in 2001 with the Australian Government committing approximately A $\$ 5$ million over three years for a new 'Family Homelessness Prevention Pilot' (FHPP). FHPP aimed to increase families' capacity to avoid homelessness; 
as well as build capacity in the local service system to respond more effectively to the needs of 'at-risk' families. This would be achieved through a bifurcated approach - working directly with 'at risk' families to help to stabilise their situation, while also working on broader systemic issues through collaborative partnerships with other providers and advocating local strategies to enhance the local community's capacity to respond to family homelessness. A Centrelink worker was embedded in each agency to help resolve issues involving assistance payments. Some agencies used part of the funding to organise social events involving clients to strengthen community ties and support networks. The FHPP commenced in late 2002 at eight pilot sites, one in each Australian state and territory. In 2004, on the basis of positive evaluation findings, the pilot program was developed into the HOME Advice Program.

The program was positioned under the National Homelessness Strategy (NHS) and managed by the Australian Government Department of Families and Community Services and Indigenous Affairs (FaCSIA). In the 2004-2005 budget, the Australian Government committed \$A10.4 million over four years to the HOME Advice Program.

\section{Intervention Trial}

Client families were referred to the HOME Advice Program by community-based welfare support agencies or a Centrelink officer based on a determination that they were 'at risk' of homelessness. From July 1, 2002 to June 30, 2007, the HOME Advice Program and the FHPP Program assisted 2,190 families including 3,177 adults and 4,584 children ${ }^{4}$. These figures include families who passed through the program and where case support was closed; as well 'open' cases being supported on June 30, 2007. Approximately 60 per cent of families supported in the HOME Advice Program were single-parent families with most headed by a female parent. About three out of ten families (29\%) were couples with children. A profile of typical HOME Advice Program families is detailed in Table 1.

Table 1

Typical Characteristics of 'at-risk' Families, 2005-2007

\begin{tabular}{|l|l|}
\hline Characteristic & Typicality (Per cent) \\
\hline Family structure & $\begin{array}{l}58 \% \text { sole-parent families (52\% female-headed households; 6\% male- } \\
\text { headed households) }\end{array}$ \\
\hline Indigenous & $27 \%$ \\
\hline Ethnic background & $14 \%$ were from culturally and linguistically diverse back grounds \\
\hline Children & $91 \%$ of families have children (the majority with 1 to 2 children) \\
\hline Income & $78 \%$ are on some type of Centrelink benefit \\
\hline Education & $65 \%$ have Year 10 level or less \\
\hline Employment Status & $81 \%$ not employed and 59\% of all families are not in the labor force \\
\hline Housing & $51 \%$ in private rental, 33\% in public rental \\
\hline Homelessness & $79 \%$ have never been homeless before \\
\hline
\end{tabular}

Source: MacKenzie et al. (2007).

While families entering the HOME Advice Program were more likely to be femaleheaded, sole-parent families with at least two children, there was a minority of male-headed, sole-parent families (6\%). The majority of HOME Advice families were on some type of Centrelink benefit and most were unemployed. While most families lived in rental housing

\footnotetext{
${ }^{4}$ Data was supplied from MacKenzie et al. (2007).
} 
(either private or public) and had never before been homeless, there was a small, but important group of families coming to the program with mortgages.

Aboriginal and Torres Strait Islander families were specifically targeted in the South Australian pilot site and just over half (57\%) of client families seeking assistance from the agency in the Northern Territory were Indigenous families. There were many similarities between the Indigenous and non-Indigenous client families, but some differences apart from cultural differences existed. Table 2 shows the characteristics of the Indigenous and nonIndigenous families entering the HOME Advice Program. Non-Indigenous families who sought support were more likely to live in private rentals, whereas Indigenous families were more likely to be in some form of public housing. Indigenous families were also more likely to be on some type of Centrelink benefit (84\% compared with $75 \%$ for non-Indigenous families) and are more mobile (40\% had three or more moves within two years compared with $22 \%$ for non-Indigenous families). Both groups present most commonly as female headed family households. A low level of educational attainment was another common factor.

Table 2

Typical characteristics of non-Indigenous and Indigenous at risk families

\begin{tabular}{|c|c|c|}
\hline & \multicolumn{2}{|l|}{ Typicality } \\
\hline Characteristic & Non-Indigenous & Indigenous \\
\hline Family structure & $60 \%$ are sole parent families & $57 \%$ are sole parent families \\
\hline Parent(s) & $\begin{array}{l}53 \% \text { are female headed } \\
\text { households }\end{array}$ & $\begin{array}{l}51 \% \text { are female headed } \\
\text { households }\end{array}$ \\
\hline Income & $\begin{array}{l}75 \% \text { receive a Centrelink } \\
\text { benefit }\end{array}$ & $\begin{array}{l}84 \% \text { receive a Centrelink } \\
\text { benefit }\end{array}$ \\
\hline Education & $\begin{array}{l}69 \% \text { have Year } 10 \text { level or } \\
\text { less }\end{array}$ & $\begin{array}{l}\text { 72\% have Year } 10 \text { level or } \\
\text { less }\end{array}$ \\
\hline Housing & $\begin{array}{l}58 \% \text { - private rental; } 27 \% \text { - } \\
\text { public rental }\end{array}$ & $\begin{array}{l}29 \% \text { - private rental; } 51 \%- \\
\text { public rental }\end{array}$ \\
\hline $\begin{array}{l}\text { Mobility in last } 2 \\
\text { years }\end{array}$ & $\begin{array}{l}22 \% \text { have moved } 3 \text { times or } \\
\text { more }\end{array}$ & $\begin{array}{l}40 \% \text { have moved } 3 \text { times or } \\
\text { more }\end{array}$ \\
\hline Homelessness & $\begin{array}{l}80 \% \text { had never been } \\
\text { homeless before }\end{array}$ & $\begin{array}{l}77 \% \text { had never been } \\
\text { homeless before }\end{array}$ \\
\hline
\end{tabular}

Source: MacKenzie et al. (2007).

Clients were assessed by agency staff to develop a list of relevant case goals for which assistance would be provided. In general, many of the families seeking help from the HOME Advice Program came with a variety of issues and needs (see Table 3). Most (83\%) had one or more problems with their living situation, which included debts affecting family life, limited employment opportunities and issues of access to services and work. Families often had poor life skills (74\%) which included poor social networking, poor social skills, and low literacy levels.

Budgeting skills were sorely lacking. In nearly two thirds of client cases (61\%), family violence and/or abuse were implicated in the families' history and experience at some stage, but not necessarily a major issue at the time the family came in contact with the HOME Advice program through a referral. About one third (36\%) of families were dealing with mental health issues.

As evident in Table 3, the two major factors impacting HOME Advice Program clients were financial factors and family violence/conflict. Factors 1, 3, and 6 relate to finances (financial stress items 1 and 3 and financial literacy item 6), while factors 4,5 , and 
10 relate to family violence. Factor 9, while not directly relating to finance, typically relates to the cost and access of public transportation particularly in areas of extreme isolation.

Table 3

Most common factors contributing to case complexity, 2005-07

\begin{tabular}{|l|l|}
\hline Factor & Per cent (\%) \\
\hline 1. Sought emergency financial assistance in the past 6 months & $51 \%$ \\
\hline 2. Few social support networks & $50 \%$ \\
\hline 3. Debt impairing family / social functioning & $51 \%$ \\
\hline 4. Family conflict & $41 \%$ \\
\hline 5. History of family violence & $40 \%$ \\
\hline 6. Poor budgeting skills & $44 \%$ \\
\hline 7. Limited employment opportunities & $40 \%$ \\
\hline 8. Mental illness indicated & $36 \%$ \\
\hline 9. No reasonable transportation to attend work & $19 \%$ \\
\hline 10. AVO/restraining/intervention order in place & $16 \%$ \\
\hline
\end{tabular}

N.B. The percentages present client cases reporting the issue affecting the management of the case as a proportion of all cases in 2005-07.

Source: MacKenzie et al. (2007).

The HOME Advice Program worked with families using a strengths-based case management practice framework which recognises all individuals and families have strengths and weaknesses in their capacity to deal with life problems. Change was brought about by drawing on a family's strengths rather than focusing on what they were not doing or could not do. The HOME Advice Program model followed a holistic approach of support by working with the issues involved in the complexity of the family's situation. Whilst addressing financial issues, support and assistance provided to families involves learning how to budget, referral to financial counselling and advice services, assisting with a current financial crisis, and resolving Centrelink (government benefit) entitlement issues.

As noted above, improving financial literacy and the ability to manage finances, thus avoiding financial stress, depends to a large extent on basic literacy. Table 4 reports educational achievement and factors contributing to case complexity of the clients in the HOME Advice Program. Educational attainment of adults of the clients in the program was found to be inversely related to seeking emergency financial assistance in the six months prior to entering the program (Chi-square $=6.96, \mathrm{df}=2, \mathrm{p}=.031$ ). There was not a clear trend though, across the three levels of educational attainment, with 59.3 per cent of people who had a low level of education and slightly less (57.9 per cent) of those with a high level of education having sought emergency financial assistance. Only 46.6 per cent of those with a medium level of education sought emergency financial assistance.

People with a medium level of educational attainment (59.0\%) were most likely to have debt impairing family or social functioning. Those with a high level of education (52.6\%) were least likely to have debt impairing family or social functioning. There was however no significant association between the level of education and debt impairment (Chisquare $=1.62, \mathrm{df}=2, \mathrm{p}=.444$ ).

Respondents with a low level of education (65.3\%) were most likely to have poor budgeting skills, followed by those with a medium level of education (39.6\%). Individuals with high levels of education were least likely to have poor budgeting skills (26.3\%). A Chisquare test indicated a significant association between education and budgeting skills (Chisquare $=31.42, \mathrm{df}=2, \mathrm{p}<.001$ ). 
Table 4

Educational achievement and factors contributing to case complexity

\begin{tabular}{|l|l|l|l|}
\hline & \multicolumn{2}{|l|}{ Factors contributing to case complexity } \\
\hline $\begin{array}{l}\text { Highest } \\
\text { completed level of } \\
\text { education }\end{array}$ & $\begin{array}{l}\text { Sought emergency } \\
\text { financial assistance in } \\
\text { the past 6 months }\end{array}$ & $\begin{array}{l}\text { Debt impairing } \\
\text { family / social } \\
\text { functioning }\end{array}$ & $\begin{array}{l}\text { Poor budgeting } \\
\text { skills }\end{array}$ \\
\hline $\begin{array}{l}\text { Low - Year 9 or } \\
\text { less }\end{array}$ & $59.3 \%$ & $53.4 \%$ & $65.3 \%$ \\
\hline $\begin{array}{l}\text { Medium - year 10 } \\
\text { - year 12 }\end{array}$ & $46.6 \%$ & $59.0 \%$ & $38.9 \%$ \\
\hline $\begin{array}{l}\text { High - Trade } \\
\text { certificate/ } \\
\text { diploma or degree }\end{array}$ & $57.9 \%$ & $52.6 \%$ & $26.3 \%$ \\
\hline
\end{tabular}

Source: MacKenzie et al. (2007).

A major aspect of the support work with at-risk families in the HOME Advice Program was assisting the family to stabilise and improve their deteriorating financial position. The most common sequence amongst client families was that they had previously sought emergency financial aid from agencies/Centrelink; however, after receiving some assistance their financial situation subsequently deteriorated further prior to joining the program.

The prevalence of goals was an indicator of whether a particular item was explicitly being dealt with during case management support. Financial issues were significant for many families and appeared high on the list of case goals. Specific financial goals included resolving immediate financial crises, making payments of arrears, accessing Centrelink entitlements, budgeting and debt reduction, and improving financial skills (see Table 5). Based upon self-reporting by HOME participants, accessing Centrelink entitlements was a goal that was fully achieved in over 90 per cent (93.3\%) of cases and partially achieved in 6.3 per cent of cases. The program model designed a strong relationship between Centrelink and the community agencies with a designated Centrelink worker available to do dedicated outreach to the agency to resolve Centrelink issues as quickly as possible.

Table 5

Prevalence and Achievement of Financial Case Plan Goals, 2005-2007

\begin{tabular}{|l|c|c|c|}
\hline \multirow{2}{*}{$\begin{array}{l}\text { Case Plan Goals in Place } \\
\text { (\% of Client Families) }\end{array}$} & \multicolumn{3}{|c|}{ Goal Completion (\%) } \\
\cline { 2 - 4 } & Fully Met & $\begin{array}{c}\text { Partially } \\
\text { Met }\end{array}$ & $\begin{array}{c}\text { Not } \\
\text { Met }\end{array}$ \\
\hline Resolve immediate financial crisis (87\%) & 53.3 & 39.9 & 6.8 \\
\hline Payment of arrears (75\%) & 40.3 & 51.2 & 8.5 \\
\hline Access Centrelink entitlements (81\%) & 93.1 & 6.3 & 0.6 \\
\hline Budgeting and debt reduction plan (80\%) & 40.3 & 47.9 & 11.7 \\
\hline Improved financial skills (51\%) & 23.0 & 62.0 & 15.0 \\
\hline
\end{tabular}

Source: MacKenzie et al. (2007).

An immediate financial crisis was fully resolved in slightly over 50 per cent (53.3\%) of cases and partially resolved in nearly 40 per cent (39.9\%) of cases. A goal for arrears to be repaid to Centrelink was fully met in 40.3 per cent of cases and partially met in 51.2 per cent of cases. These figures support the observation of agency and Centrelink workers that some 
aspects of financial stress can be sorted out quickly and substantially. Dealing with such issues can be considered to be part of the financial counselling process.

Undertaking further training, gaining employment or learning new skills in managing household budgets to improve a family's financial situation may take considerable time. Where this goal was relevant in the casework, some 85 per cent of client families made progress, with goals fully met in 23 per cent and goals partially met in 62 per cent of cases. However, a low level of family income probably means that financial management will remain a continuing challenge for most of the families passing through the program. Financial crisis and accumulating debt accompanied with other issues was the typical pattern for families entering the HOME Advice Program (see Table 6).

Table 6

Change in level of reported debt, 2005-07

\begin{tabular}{|l|l|}
\hline Change & Change in Level of Debt (\%) \\
\hline Reduced to zero & $10 \%$ \\
\hline Reduced & $55 \%$ \\
\hline Remained the same & $33 \%$ \\
\hline Increased & $2 \%$ \\
\hline Total & $100 \%$ \\
\hline
\end{tabular}

Source: MacKenzie et al. (2007)

Ten per cent of clients left the program with no debt (i.e. debt reduced to zero). A little more than half of the clients (55\%) reduced their debts while in the program. For about one third of clients (33\%) debt remained about the same and for two per cent of clients, debt actually increased. About one quarter of families had no information recorded against debt before and after support, however, they had other issues that placed them 'at risk' of homelessness. There were a small number of families who had mortgages and they were more likely to report no change in their debt position but none said their debt had worsened. Clearly what was achieved in terms of debt reduction was in large part dependant on the size and nature of the debts. Overall, these results suggest a significant improvement for most families.

\section{Conclusions and Policy Implications and Recommendations for Future Research}

Hill's ABCX model (1949 and 1958) of family stress proposed that resources and social support provided by the community (Hill's first protective factor) can moderate the negative impact of stressful events. In the case of the HOME Advice Program support was provided to clients according to their identified needs. To address the financial issues causing clients financial stress support was provided in the form of financial counseling and internal family resources were enhanced through financial literacy training. Analysis of the data from the HOME Advice Program Evaluation provides support for the notion that financial counselling and literacy training can moderate the impact of families experiencing financial stress. Specifically, we found substantial immediate benefits to the client group from such support.

A more in-depth analysis of the results of The Home Advice Program than is presented here is not possible due to the construction of the program. For example the pilot was not constructed with an experimental design which randomly assigned 'at risk' families into experimental and control groups. While this is unfortunate it does not invalidate the worth of the program. The early intervention case management and support provided by the HOME Advice Program was measurably successful in terms of resolving immediate financial 
crises and reducing debt levels even in the most complex cases. What impact case support might have over the longer-term remains.

It should be noted that the cost per client in the HOME Advice Program was lower than the cost per client of the Australian Governments' homelessness assistance program (SAAP) that provided housing and assistance to families and individuals who experience homeless. The lower cost of early intervention is consistent with cost-benefit arguments about the financial benefit of early intervention rather than waiting to provide services to people once they are homeless.

As a component of most homelessness programs financial counselling addresses immediate financial issues. The HOME Advice Program differed from many existing homeless programs by emphasizing capacity-building through an effort to improve financial literacy and budgeting skills in addition to resolving immediate crises. However financial literacy takes time to develop and depends on basic literacy skills. Policies that aim to reduce school truancy and increase school retention rates have been noted as being important in improving general literacy may result in improving financial literacy over time (Betal 2004).

An implication of the findings from the HOME Advice Program is that improving financial literacy could be an important part of early intervention and prevention initiatives. The issue remains as though to what elements of financial literacy should be taught, when these should be taught and how long the benefits of such programs last (see McCormick (2009) for a summary of the research relating to youth financial education and policy). A follow up of HOME Advice clients who received assistance in terms of financial literacy support could provide supportive data on the long term benefit of such interventions. It should be remembered that the HOME Advice Program focused on families at-risk of homelessness. Further research is needed to investigate the impact of financial counselling and financial literacy programs on families which are already homeless.

Wagland and Taylor (2009) have suggested "targeted educational programs could be designed to improve financial literacy generally for the broader Australian community resulting in widespread benefits" (p. 23). Similarly, the Australian Securities and Investments Commission's (2003) Financial Literacy in Schools report championed financial literacy programs inside and outside of schools. Others have called for a national partnership of stakeholders in Australia to improve financial literacy levels, especially in the elderly, youth, and socially disadvantaged (Institute of Chartered Accountants in Australia, 2003). While there is widespread support for such programs the suggestion that improved financial literacy alone will be enough to eliminate financial stress and its most serious consequences such as homelessness cannot be supported. Even if standards of general literacy and numeracy can be lifted, and appropriate financial literacy programs successfully initiated across the community, timely intervention in terms of crisis support and financial counselling will still be needed. However, to the extent that improved financial literacy builds family capacity to manage their finances better and cope with crises will be of benefit to the economy, support the financial services sector, and serve to reduce social and economic exclusion. What our overview of the literature has revealed is that there needs to be more evidence of the short and long term benefits of financial literacy programs. In particular, the costs and benefits of financial literacy programs as opposed to financial counselling or in combination with financial counselling. 


\section{References}

Anderson, I, Kemp, P \& Quilgars, D 1993. Single Homeless People, The Department of the Environment Report, London HMSO.

Australia and New Zealand Banking Group Limited (ANZ) 2005. Understanding personal debt \& financial difficulty in Australia. Macquarie Park, NSW: ACNielsen.

Australia and New Zealand Banking Group Limited (ANZ) 2008. ANZ Survey of Adult Financial Literacy in Australia, accessed date 15/12/2010, http://www.anz.com/Documents/AU/Aboutanz/AN_5654_Adult_Fin_Lit_Report_08_Web_R eport_full.pdf.

Australian Law Reform Commission 1997. Seen and heard: priority for children in the legal process accessed date 15/12/2010, austlii.edu.au/au/other/alrc/publications/reports/84/ALRC84.html

Australian Securities and Investments Commission 2003. Financial literacy in schools, accessed date 15/12/2010. asic.gov.au/asic/pdflib.nsf/LookupByFileName/FinLit_schools_DP.pdf/\$file/FinLit_schools_ DP.pdf

Berger, P, S \& Tremblay, K, R 1999. 'Welfare Reform's Impact on Homelessness', Journal of Social Stress and the Homeless, vol.8, no.1, pp1-20.

Betal, D 2004. Getting a life: Helping homeless people get back on their feet, London: St Mungo's.

Boheim, R \& Taylor, M, P 2000. 'My home was my castle: evictions and repossessions in Britain', Journal of Housing Economics, vol.9, no.4, pp287-319.

Bray, J, R 2001. Hardship in Australia: An analysis of financial stress indicators in the 1998-1999, Occasional Paper No 4, Australian Bureau of Statistics Household Expenditure Survey, accessed date 15/12/2010, http://www.fahcsia.gov.au/about/publicationsarticles/research/occasional/Documents/op04/N o.4.pdf.

Breunig, R \& Cobb-Clark, D 2004. Understanding the factors associated with financial stress in Australian households: Social Policy Evaluation Analysis and Research Centre: The Australian National University.

Burgess, L \& Roberts, C 2003. The Centrecare National Family Homelessness Project - A Family and Community Services (FaCS) Funded Project under the National Homelessness Strategy, Parity, 16(9): 6-9.

Centrepoint 2005. Too Much Too Young. Problem debt amongst homeless young people. London, Centrepoint.

Chamberlain, C \& MacKenzie, D, J 2001. Counting the Homeless, Australian Bureau of Statistics, Canberra.

Chant Link and Associates 2004. A report on financial exclusion in Australia. accessed date 15/12/2010, http://anz.com/aus/aboutanz/community/programs/pdf/financialexclusionfinalreport.pdf

Chatzky, J 2002. 'Teach our children well', Money, vol.31, p128.

Commonwealth of Australia 2008. The Road Home: A National Approach to Reducing Homelessness, AGPS Canberra.

Connolly, C, Georgouras, M, Hems, L \& Wolfson, L 2011. Measuring financial exclusion in Australia, Centre for Social Impact (CSI) University of New South Wales for the National Australia Bank.

Corden, A \& Hirst, M 2007. 'Exploring the financial implications of death of a life partner: Using a mixed methods approach', Paper for presentation at the $3^{\text {rd }}$ Annual International Mixed Methods Conference at Fitzwilliam College, Cambridge UK 9-11 July.

Crane, M \& Warnes, A, M 2001. 'Older people and homelessness: Prevalence and causes', Topics in Geriatric Rehabilitation, vol.16, pp1-14.

Crane, M, Byrne, K, Fu, R, Lipmann, B, Mirabelli, F, Rota-Bartelink, A, Ryan, M,R, Watt, H \& Warnes, A,M 2005. 'The causes of homelessness in later life: findings from a 3-nation study', The Journals of Gerontology: Series B, vol.60, no.3, ppS152-S159. 
Darbyshire, J,P, Muir-Cochrane, E, Fereday, J \& Jureidini, J 2006. 'Engagement with health and social care services: perceptions of homeless young people with mental health problems', Health \& Social Care in the Community, vol.14,no.6, pp553-562.

de Clercq, B \& Venter, J, M, P 2009. 'Factors influencing a prospective chartered accountant's level of financial literacy: an exploratory study', Meditari Accountancy Research, vol.17, no.2, pp47-60.

De Panfilis, D 1999. 'How do I determine if a child is neglected', in H. Dubowitz \& D. De Panfilis. (Eds.), Handbook for Child Protection Practice, London Sage.

Eisenhardt, K, M 1989. 'Building theories from case study research', Academy of Management Review, 14(4), 532-550

Flatau, P, Martin, R, Zaretzky, K, Haigh, Y, Brady, M, Cooper, L, Edwards, D \& Goulding, D 2006. The effectiveness and cost-effectiveness of homelessness prevention and assistance programs, Australian Housing and Urban Research Institute Western Australian Research Centre (AHURI) Positioning Paper No. 92.

Garman, E, T, Kim, J, Kratzer, C, Y, Brunson, B, H \& Joo, S, H 1999. 'Workplace financial education improves personal financial wellness', Financial Counselling and Planning Journal, vol.10, pp79-99.

Gowdy, E, A, Rapp, C, A \& Poertner, J 1993. 'Management Is Performance: Strategies for ClientCentred Practice and Social Service Organsiations', Administration and Social Work, vol.17, no.1 pp 3-22.

Gutman, L, M, McLoyd, V, C \& Tokoyawa. T 2005. 'Financial strain, neighbourhood stress, parenting behaviours, and adolescent adjustment in urban African American families', Journal of Research on Adolescence, vol.5, no.4, pp425-449.

Hill, R 1949. Families under stress: Adjustment to the crises of war separation and reunion. New York: Harper \& Brothers.

Hill, R 1958. 'Generic features of families under stress', Social Casework, vol.49, pp139-150.

Huddleston, CA \& Danes, S M 1999, 'Impact evaluation of a financial literacy program: evidence for needed educational policy changes', Consumer Interests Annual, vol.45, pp109-115.

Huston S, J 2010. 'Measuring financial literacy', Journal of Consumer Affairs, vol.44, no.2,pp 296316.

Institute of Chartered Accountants in Australia 2003. 'Financial literacy levels grim', Charter Vol.74, no.18.

Jumpstart Coalition for Personal Financial Literacy 2005. 2004 Personal financial survey of high school seniors, June. accessed date 15/12/2010, http:jumpstartcoalition.com/upload/Executive\%20Summary.doc

Kemp, P, Bradshaw, J, Dornan, P, Finch, N \& Mayew, E 2004. Roots out of poverty, A Research Review, York UK, Joseph Rowntree Foundation.

MacKenzie, D, Desmond, K \& Steen, A 2007. Household Organisational Management Expenses Advice Program Evaluation Report, Commonwealth Department of Families, Housing, Community Services and Indigenous Affairs. Commonwealth of Australia, Canberra.

Mandell, L 1998. Our vulnerable youth: the financial literacy of American 12th graders, Washington: Jumpstart Coalition for Personal Financial Literacy.

Marks, G, N 2007. Income poverty, subjective poverty and financial stress. Social Policy Research Paper No. 29, accessed date 15/12/2010, http://www.fahcsia.gov.au/about/publicationsarticles/research/socialpolicy/Documents/prp29/ sprp29.pdf

Marston, G \& Shevellar, L 2010. The experience of using fringe lenders in Queensland: A pilot study: Social Policy Unit, The University of Queensland.

McCormick, M, H 2009. The Effectiveness of Youth Financial Education: A Review of the Literature, Networks Financial Institute, New America Foundation \& Citi Foundation. accessed date $15 / 12 / 2010$, http://www.newamerica.net/publications/policy/effectiveness_youth_financial_education_0

McCubbin, H, I \& Patterson, J, M 1982. 'Family adaptation to crisis', in H. I. McCubbin, A. E. Cauble, \& J. M. Patterson (eds.), Family stress, coping, and social support. Springfield, IL: Charles C. Thomas. 
McCubbin, H, I \& Patterson, J, M 1983a. 'Family stress and adaptation to crises: A Double ABCX Model of family behavior', in D. H. Olson \& R. C. Miller (Eds.), Family studies review yearbook: vol.1, pp87-106, Beverly Hills, CA: Sage.

McCubbin, H, I \& Patterson, J, M 1983b. 'The family stress process: The Double ABCX Model of family adjustment and adaptation', in H. I. McCubbin, M. Sussman, \& J. M. Patterson (eds.), Social stress and the family: Advances and developments in family stress theory and research, pp 7-37, New York: Haworth.

Moore, T, McArthur, M \& Noble-Carr, D 2009. 'Lessons learned from children who have experienced homelessness: what services need to know'. Children \& Society. no. http://dx.doi.org/10.1111/j.1099-0860.2009.00270.x

Norman, A, S 2010. 'Importance of financial education in making informed decision on spending', Journal of Economics and International Finance, vol.2, no.10, pp199-207.

O'Neill, B, H, Lytton, R, H \& Parrott, K, R 1995. 'Living on the edge: Characteristics and practices of overextended homeowners’, Family Economics and Resource Management Biennial, pp109114.

Relationships Australia 2008. Relationships indicators survey 2008: Issues and Concerns that Australians have in their relationships today, accessed date 15/12/2010, http://www.relationships.com.au/resources/pdfs/reports-submissions/ra-rel-ind-survey-2008report.pdf.

Roberts, C \& Burgess, L 2004. A Longitudinal Research Project on Aboriginal Homelessness in Perth, Western Australia, National Family Homelessness Project, Commonwealth Department of Families and Community Services and Indigenous Affairs, Commonwealth of Australia , Canberra.

Roy Morgan Research 2003a., ANZ Survey of Adult Financial Literacy in Australia: Final Report, Melbourne: ANZ Bank. 19.

Roy Morgan Research 2003b. ANZ Survey of Adult Financial Literacy in Australia: Stage 2: Telephone Survey Report, Melbourne: ANZ Bank.

Roy Morgan Research 2003c. ANZ Survey of Adult Financial Literacy in Australia: Stage 3: In-Depth Interview Survey Report, Melbourne: ANZ Bank.

Saunders, M, Lewis, P. \& Thornhill, A 2007. Research Methods for Business Students, 4th edn. Harlow, UK: Prentice Hall.

Saunders, P 1998. Using budget standards to assess well-being of families, Social Policy Research Centre, University of New South Wales, Sydney.

Schagen, S \& Lines, A 1996. Financial literacy in adult life: a report to the Natwest Group Charitable Trust, Slough, Berkshire: National Foundation for Educational Research.

Vissing, Y 2007. 'A roof over their head: Applied research issues and dilemmas in the investigation of homeless children and youth,' in A. L. Best (ed.), Representing youth, pp 110-132, New York: New York University Press.

Wagland, S, P \& Taylor, S 2009. 'When it Comes to Financial Literacy, is Gender Really an Issue?' The Australasian Accounting, Business \& Finance Journal, vol.3, no.1, pp13-25.

Wallace, A \& Quilgars, D 2005. Homelessness and Financial Exclusion: a literature review, London: Friends Provident and London Housing Foundation.

Wehler, C, Weinreb, L, F, Huntington, N, Scott, R, Hosmer, D, Fletcher, K, Goldberg, R \& Gundersen, C 2004. 'Risk and protective factors for adult and child hunger among lowincome housed and homeless female-headed families', American Journal of Public Health, vol.94, no.1, pp109-115.

Wesley Mission 2006. 'Financial Stress and its impacts on the individual family and the community', Wesley Mission Research Department, accessed date 30/6/2011, http://www.wesleymission.org.au/news/publications/finstress/financial_stress_report.pdf

Winkworth, G, Thompson, M, McArthur, M, Thomson, L, \& Wilson, F 2009. Working in the grey: Increasing collaboration between services in inner North Canberra. A Communities for Children Project Canberra: Institute of Child Protection Studies, Australian Catholic University.

Worthington, A, C 2006a. 'Predicting financial literacy in Australia', Financial Services Review, vol.15, no.1, pp59-79. 
AABFJ | Volume 7, no. 3, 2013

Worthington, A, C 2006b. 'Debt as a source of financial stress in Australian households', International Journal of Consumer Studies, vol.30, no.1, pp2-15.

Yates, J 2007. Housing affordability and financial stress, Australian Housing and Urban Research Institute, Sydney Research Centre, Research Paper No 6.

Yin, R, K 2003. Case Study Research: Design and Methods, $3^{\text {rd }}$ edn., Thousand Oaks: Sage Publications. 